\title{
The Sources of Microfinance Capital and its Effects on Farmers access to Credit in
}

\section{Ghana}

\author{
Anane, I. ${ }^{1}$, Y. Zhang ${ }^{2}$, F.Y. Nie ${ }^{1, *}$ \\ ${ }^{1}$ Graduate School of Chinese Academy of Agricultural Sciences, Agricultural Information Institute, \\ Beijing 100081, P.R. China. \\ ${ }^{2}$ College of Economics and Management, China Agricultural University, Haidian District, Beijing \\ 100083, P.R. China,
}

\begin{abstract}
Farmers in Ghana face difficulties in accessing microfinance credit, and as a result, there is low accessibility to microfinance credit. This study explores the effects of sources of microfinance capital on farmers' access to credit. A total of 2734 individual household members were used in the final analysis to establish the relationship between the sources of microfinance capital and farmers' access to microfinance credit. The participants include clients of selected microfinance institutions and nonclient households. Logistic regression models were employed for data analyses. The study has shown that microfinance capital's source significantly influences farmers' access to credit. The analysis further revealed that land ownership, gender, and literacy strongly correlate with farmers' access to credit. The study has also established that savings account, microfinance membership, and geographical location significantly influence the credit providers' decision-making process to grant a loan to the customer. Our findings suggest that microfinance institutions have not been able to perform their business effectively because of capitalization. Sensitization programs are needed to enable microfinance institutions to configure innovative financing methods to improve capitalization. There is a need to improve the sources of funds and capital mobilization to maximize their financial performance and increase farmers' access to credit. Education to farmers to understand credit providers' requirements can also increase farmers' access to microfinance credit.
\end{abstract}

Keywords: Microfinance, Farmers, Credit, Ghana, Capital

\section{Introduction}

As in most developing countries, agriculture plays a crucial role in Ghana's economic development - it employs the largest share of the country's labour force $(53.6 \%)$ and contributing $22 \%$ to its national GDP (FAO, 2015). However, Ghana's agricultural

\section{*Corresponding author: Fengying Nie}

Email: niefengying@caas.cn

Received: February 3, 2021;

Accepted: March 3, 2021;

Published: March 23, 2021. production has fallen since 1960 due to the decline in commodity price, reduced incentives for farm production, and inadequate investments in necessary infrastructure by the government (Berry, 1995). The decline in agricultural production has resulted in various problems such as food insecurity, malnutrition, excessive importation of food items, and rising inflation. Farmers over the years in Ghana have used rudimentary agricultural technology 
because of financial challenges. Rain-fed agriculture and very few or no irrigation systems, inadequate agrarian input such as seed and fertilizer are a few examples.

Microfinance has been proposed to solve these problems (Anderson et al., 2002; Berhane and Gardebroek, 2011; Swain and Wallentin, 2009). Microfinance spans a range of financial instruments, including credit, savings, insurance, mortgages, and retirement plans. These are denominated in a small amount, making them accessible to individuals previously shut out from formal means of borrowing and savings (Khavul, 2010). Microfinance contribution has made a significant impact on income, savings, expenditure, and assets accumulation, as well as non-financial outcomes, including health, nutrition, food security, education, women's empowerment, job creation (Van Rooyen, Stewart, and De Wet, 2012). It has also contributed immensely to the economic development of Ghana. However, it is estimated that only $5 \%$ of the farmers in Africa and about 15\% in Asia and Latin America have had access to formal credit. On average, across developing countries, $5 \%$ of the borrowers have received $80 \%$ of the loan (Bali, 2001). The small number shows a gap in farmers' financial access, and Ghana is facing a similar problem. In most cases, the decision to offer credit or the size of the loan requested by the borrower is based on quantity rationing by using price rationing as a tool (Stiglitz and Weiss, 1981). However, other studies have been developed to include other non-price rationing policies. A survey by Boucher and Guirkinger (2007) reviewed two additional means by which asymmetric information may affect households' terms of access to the credit market and their resource allocation decision. First, banks may pass on to borrowers the transaction costs associated with screening applicants, monitoring borrowers, and enforcing contracts. Second, lenders may require borrowers to bear significant contractual risks to mitigate moral hazard. They concluded that these credit-rationing methods are the main constraints for farmers to access credit.

Dzadze et al. (2012), Chauke et al. (2013), Kiplimo (2013), Mohammed et al. (2013), and Nouman et al. (2013) employed logistic regression to estimate the factors that influence the decision making process by agricultural credit suppliers. They reviewed that the typical household characteristics that influence lenders' decision to grant household farmers' access to microfinance credit include social capitals such as homogeneity, network connection, and socio-economic factors such as the farmers' income level, education, age, marital status, farming experience, farm size. The government of Ghana carried out a series of measures to improve the agricultural sector, including establishing an Agricultural Development bank in 1965 and the Export Development and Investment Fund's founding in 2000. (State and co-operative farms were established to produce crops, such as rice and corn. In 1965, the Agricultural Development Bank was set up to provide credit to crop and livestock farmers and small agribusiness. In 1972, the policy of "Operation Feed Yourself" was set up as result of drought and bush fire that occurred in that period. In order to support agriculture and other rural activities Rural and community Banks were launched. The Export Development and Investment Fund (EDAIF) was set up in 2000 to finance Ghana's trade). Echoing these governmental interventions, the Bank of Ghana initiated numerous projects that intended to improve agricultural outputs, such as the Cocoa 
Bill Financing Scheme (1958), Grains Bill Financing Scheme (the mid-1970s), and Grains Warehousing Company (1975), among others. Targeting small-scale businesses and farming activities run by low-income clients, these policies have rendered microfinance a household name for rural finance in Ghana, which provides financial services through a range of products and a system of intermediary functions.

Nevertheless, much less is known about who can successfully obtain credit from microfinance institutions in Ghana. Many studies have discussed factors that impede the farmer's access to agricultural credit. Most of these studies focus on agrarian credit borrowers. These researchers mostly draw their attention to household characteristics, asset ownership, regional characteristics (Kedir, 2003; Ferede, 2012; Anang et al., 2015; Linh et al., 2019). One key factor missing from the theory is the sources of microfinance capital and access to credit. Those studies that slightly touch microfinance capital sources link their studies on financial sustainability, self-sufficiency, and outreach (Fehr and Hishigsuren, 2006; Bogan, 2012; Kar, 2012; Ngo, 2013; Sekabira, 2013). It is essential to assess access to credit from both providers' and customers perspective' thoroughly. As a better means to inform policymakers and close the knowledge gap, this present study seeks to establish microfinance capital sources' effect on Ghanaian farmers' access to microfinance credit. Besides, the major studies conducted in Ghana limited their sample to the same region or district, as in Anang et al. (2015). This study sought to find data, which has a large sample size and nationally representative. This information is vital for policymakers in taking appropriate actions toward facilitating comprehensive and sustainable financial institutions to develop agriculture and rural finance. The study results also stand to benefit the development partners and civil society organizations involved in providing credit facilities to small farmers and countryside micro-enterprise sectors in modifying source of finance and better conditions to serve the specific credit and savings needs of their clients.

\section{Conceptual framework}

The following variables were tested based on the problem statement and relevant literature to know the statistical significance between farmers' access to credit and microfinance sources of capital (Agier and Szafarz, 2013; btissem and Bouri, 2013; Stiglitz and Weiss, 1981). Many factors inform the decisionmaking process by lenders of agricultural loans. These mechanisms are put in place by all microfinance institutions worldwide to tackle credit standards, assess return on credit, evaluate risk on loan to farm, and transaction cost (Langat, 2013). Indeed, lenders are the ones who determine whether borrowers can obtain credits depending on the information available about borrowers (Zeller, 1994). Microfinance institutions' conditions mostly differ among institutions based on operations' nature (Umanath et al., 2018). Given this background of agricultural credit approval or rejection by the lenders, there is a need to examine the factors that usually informed the decision-making process. Based on the previous assumptions, the study area, and researchers' experience from the various households, the following factors were considered the critical determinants of agricultural credit by lenders. 


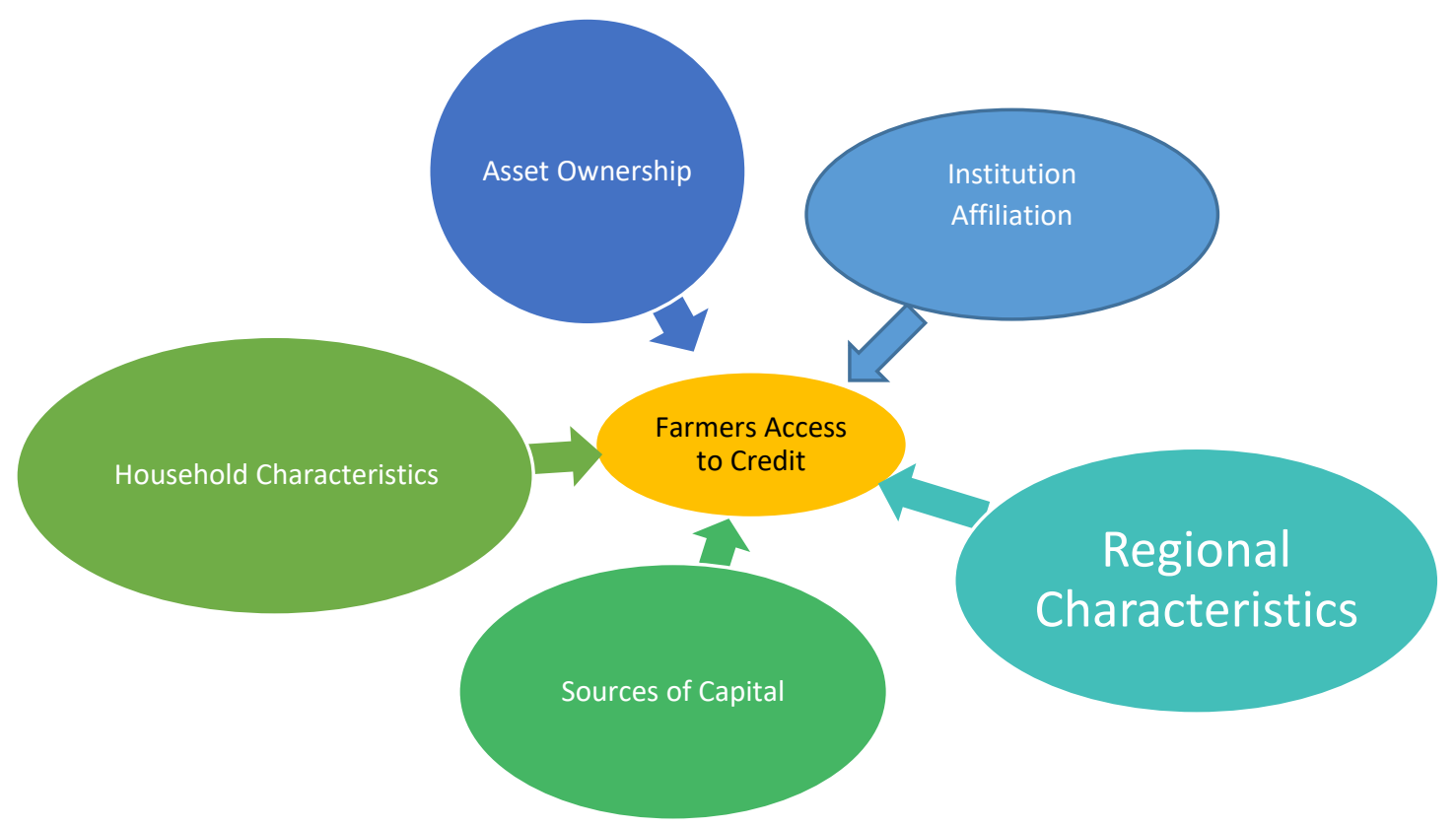

Figure 1. Conceptual framework

Sources of microfinance capital play a significant role. In most cases, different capitalization determines financial strength (Parvin et al., 2020). A weak source or overreliance on the donor is likely to affect microfinance operation and credit distribution (Bhanot and Bapat, 2015; Al-Mamun et al., 2014). The source of finance here indicates the various means by which microfinance institutions acquired capital to give out loans. Microfinance institutions mostly get their capital from the government, NGO-donor agencies, and microfinance owner's equity. If microfinance has a weak source of finance and highly depends on the third party for capitalizations, it will directly affect the business operations. As such, it affects credit distributions. Thus, this study hypothesizes that sources of microfinance capital affect the farmers' access to credit.

Asset ownership greatly influences the decision-making in the microfinance credit rationing (Diaz-Serrano and Sackey, 2018).
Agricultural credit lenders use an asset's ownership to measure the client's wealth, repayment ability (Henning et al., 2019). Lenders mostly use the ownership of assets such as land and houses to measure farmers' income levels to ensure credit repayment. Therefore, these variables were expected to have a positive correlation with access to credit. Household characteristics also come into play when microfinance lenders decide to give agricultural credit. Household characteristics such as gender, marital status, literacy, family size, and food constraints are vital determinants of credit by microfinance credit (Sekyi, 2017). Microfinance credit providers use this factor to determine credit borrowers' creditworthiness, household responsibility, loan diversion, and education level (Santandreu et al., 2020; Hemtanon and Gan, 2020). This study hypothesized that a high level of education, large family size, married people, and females would increase farmers' access to credit and vice versa. 
Geographical location can also influence household access to agricultural credit (Li et al., 2011). The proximity of an individual household to a microfinance institute can be a determinant factor. Ghana is divided into ten administrative regions, and this presupposes that a single household located closer to microfinance institutions will have a higher chance of accessing microfinance credit.

An institution affiliation is also another factor that can have an impact on access to agricultural credit. Microfinance credit providers use this factor to measure customers' credit management experience, savings habits, and credit history (Agier and Szafarz, 2013; btissem and Bouri, 2013). Also, the type of microfinance institution and its operations significantly influence household access to credit. This present study expects that individual household farmer who has a savings account, member of microfinance and good credit history will positively affect credit access. To this end, the model empirically attempts to assess the effects of sources of microfinance sources' capital on Ghanaian farmer's access to credit. Four other sets of factors are asset ownership, household characteristics, geographical and institutional affiliations.

The rest of this paper is structured as follows. Section 2 introduces our data and develops an econometric model to estimate the determinants of Ghanaian farmers' access to credit. Section 3 reports and discusses our empirical results. The final section concludes the paper and offers some suggestions.

\section{Material and Methods}

\subsection{Data sources}

The data used in this study were drawn from a survey conducted by Inter-University Consortium for Political and Social Research (ICPSR), USA, as part of its program to conduct poverty assessment and a comparative study of Rural Microfinance Institutions and Government Programs in Ghana (Annim et al., 2014). The survey divided the country into three different zones to get a national representative sample size. They include Northern Zone comprises Northern, Upper West, Upper East region of the country; Middle zone consists of Ashanti, Bono Ahafo and Eastern region; Coastal zone covers Greater Accra, Volta, Central, and Western Regions. Clients were selected from 17 microfinance institutions in all the zones. The selected institutions include savings and loans companies, rural banks, credit unions, financial non-governmental organizations, and susu groups. Selected clients who had loans in the past six months or were short-listed to receive loans in the household were interviewed. The study used a two-stage sampling procedure to select clients from the household. First, a purposive sampling procedure was used to select the number of clients by program per institution. Secondly, the study used a simple random technique for the selection of households. Overall, 1104 household non-client countrywide was selected, and 1630 clients from microfinance institutions were successfully interviewed for the data analysis. Demographic information collected includes age, education, sex, the health status of all household members aged 15 and above, religion, marital status. 


\subsection{Empirical specification}

This study uses the logistic regression model to analyze microfinance capital sources' effect on farmers' access to credit in Ghana. The model was used to assess the effect of microfinance capital sources on farmers' access to credit.

According to Zumel (2014), the logit model assumes that the log-odds of an observation $y$ can be expressed as a linear function of the $\mathrm{K}$ input variables $\mathbf{x}$ :

$\log \frac{P(X)}{1-P(X)}=\sum_{j=0}^{K} b_{j} x_{j}$

The model logistic regression is in the form $\log \frac{P(X)}{1-P(X)}=\beta_{0}+x \cdot \beta$

Since the logistic function uses maximum likelihood for parameter estimation, we can fit using likelihood. Considering $\mathrm{N}$ samples with labels either 0 or 1 . The probability of that sample was either $\mathrm{p}(\mathrm{x})$ if $\mathrm{y}_{\mathrm{i}}=1$ or $1-p(\mathrm{x})$ if $\mathrm{y}=0$. Then, from Newton, numerical estimation method gives us

$p(X)=\frac{1}{1+e^{-\beta X}}$

Specifically, the generic form of the econometric will be as follows:

\section{Access to credit}

$$
\begin{aligned}
& =\beta_{0}+\beta_{1} S O C+\beta_{2} X \\
& +\varepsilon \ldots \text { (1) }
\end{aligned}
$$

In equation (1), the dependable variable, Access to credit, indicates whether a farmer has access to microfinance credit or not. $\boldsymbol{\beta}$ 's are coefficients to be estimated, and $\boldsymbol{\varepsilon}$ is the error terms. The primary variable of interest in equation (1), SOC measures the source of microfinance capital. Based on the conceptual framework, relevant literature, and available evidence, the variables assumed to have influence include asset ownership, household characteristics, institution affiliations, and regional variable (Agier and Szafarz, 2013; btissem and Bouri, 2013; Stiglitz and Weiss, 1981; Sekyi, 2017). The study used an econometric model to explore the effects of microfinance capital sources' on farmers' access to microfinance credit. The empirical model is specified as follows:

$$
\begin{aligned}
Y=\left(\beta_{0}+\beta_{1}\right. & \text { soc } \\
& +\beta_{2} \text { ownL }+\beta_{3} \text { ownH } \\
& +\beta_{3} \text { ownCar }+\beta_{4} \text { ms }+\beta_{5} \text { Age } \\
& +\beta_{6} \text { Sex }+\beta_{7} \text { Famsize } \\
& +\beta_{9} \text { literacy } \\
& +\beta_{10} \text { MFImember } \\
& \left.+\beta_{12} \text { Savings }+\beta_{13} \text { Location }\right)
\end{aligned}
$$

Where $\mathrm{Y}$ is the dependant variable defined as a farmer has access to credit $=1$ and 0 otherwise; $\beta_{0}$ is constant and intercept of the equation. The measurement/definitions and summary statistics of all the variables are presented in Table 1 below.

(Greene, 2003) has noted that the binary choice models' parameters, like those of any nonlinear regression model, are not necessarily the marginal effects. As noted by Cameron and Trivedi (2010, p.343) a marginal effect (ME) most measures the effect on the conditional mean of $y$ of a change in one of the regressors, say, $x_{j}$

This study made a considerable effort on robustness to address potential bias estimates that result from critical variable omissions, small sample size, and sample selections. Concerning the omitted variables problem, a great effort was made to reduce it by introducing more independent variables (household characteristics, asset ownership, institution affiliations). These variables were commonly used in previous studies. These variables made it possible to check for heterogeneity across the household and serve as a new evidence base for other factors other than the primary variable of interest. Secondly, the 
small sample size and sample selection problems were also kept in mind. The study made an effort to choose nationally representative data. The study applied robust standard errors in the linear regression model. Furthermore, the study conducted a collinearity diagnostic test to check for possible multicollinearity. However, all variance inflation factor $(V I F)$ values were $<10$, indicating that multicollinearity is not a major issue. The study used average marginal effects in its interpretation. Average marginal effects are known from the literature to gives a more intuitive description of logistics regression. Average marginal effects are known to provide a single magnitude summary that reveals X's full distribution rather than a random prediction, and they can capture variability (Leeper, 2017).

Table 1. Definitions and Summary Statistics of Variables.

\begin{tabular}{llll}
\hline (1) & (2) & (3) & (4) \\
Variable & Definition & Mean & SD \\
\hline Farmers' access to credit & the value of 1 when farmers have access to & 0.56 & 0.50 \\
& $\begin{array}{l}\text { credit and 0 otherwise } \\
\text { Source of capital }\end{array}$ & 1.43 & 1.32 \\
Asset ownership & sources of MFI capital & & \\
Ownership of land & Value of 1 if owns land, 0 if no & 0.55 & 0.50 \\
Ownership of house & Value of 1 if owns house, 0 if no & 0.40 & 0.49 \\
Ownership of car & Value of 1if owns a car, 0 if no & 0.06 & 0.24 \\
Household characteristics & & & \\
Marital status & Value of 1 if married, 0 single & 1.76 & 0.43 \\
Gender & Value of 1 if male, 0 if female & 0.54 & 0.50 \\
Household size & Number of people in the household & 5.24 & 2.48 \\
Literacy & No. of a literate adult in the household & 1.98 & 1.72 \\
Age & Age of the respondent & 47.11 & 2.50 \\
Institution Affiliation & & & \\
Savings account & Own savings 1, 0 if no & 0.65 & 0.74 \\
Member of MFI & A member of MFI & 1.24 & 1.44 \\
Geographical area & & 4.28 & 2.02 \\
Location & Geographical location & & \\
\hline & & & \\
\hline
\end{tabular}




\section{Results and Discussions}

\subsection{Descriptive analysis}

Sources of the loan and the distribution of loan size;Farmers in Ghana mostly obtain their credit from microfinance institutions, including rural banks, rural cooperatives, credit unions, nongovernmental organizations (NGOs), savings and loans (S\&Ls) companies, and Susu Collectors (Susu a concept used in Ghana refers to an informal means of collecting and saving money by group of people. An amount collected by members are put into one pot and the money is paid to one person in regular time interval usually a month until they hand down.). Figure 1 shows the distribution sources of finance for farmers in the sample. Rural banks constitute an essential source $-63.8 \%$ of farmers in our sample obtained their credit from them. NGOs serve as the second-largest source; $27.5 \%$ of the sample farmers received their loans, usually in training and credit. Another two sources are farmers' cooperative societies, $4.4 \%$, and Susu (1.8\%). Finally, $2.46 \%$ of farmers in the sample obtained their credit from savings and loan companies.

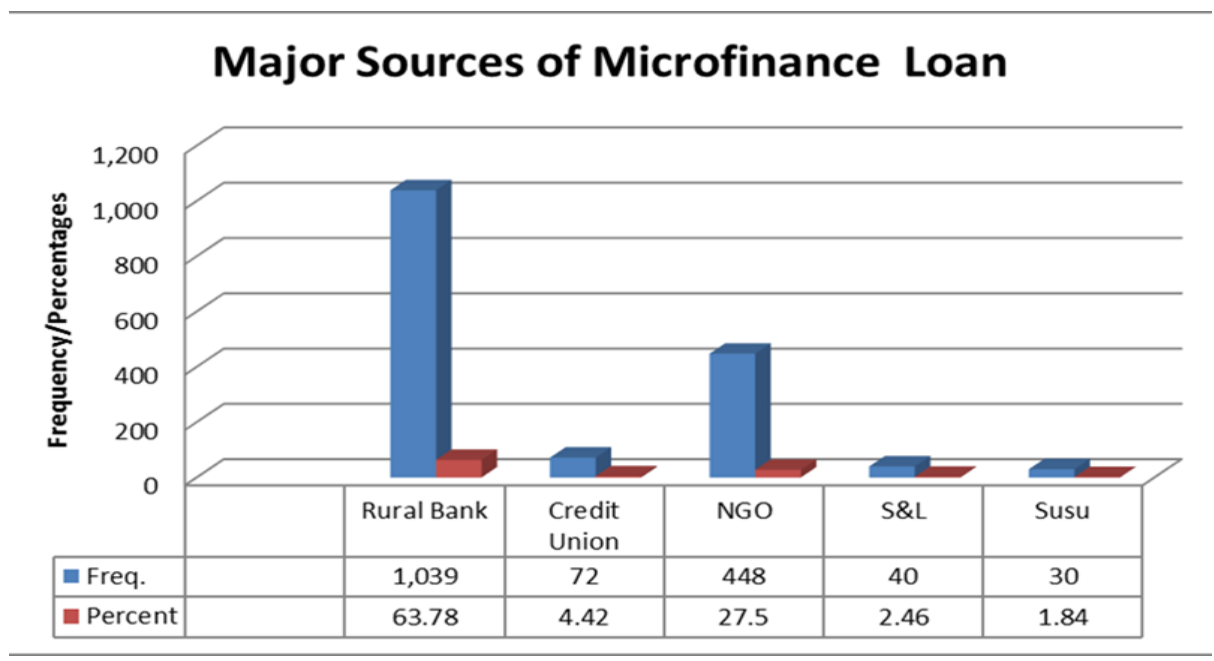

Figure 2. Major Sources of Microfinance Credit

Table 2 shows the distribution of loan size by microfinance institutions, depicting the number of farmers who had access to microfinance credit. $22.42 \%, 33.04 \%$, and 20.68 received an amount ranges between $\mathrm{GH} \phi$ 250- 499.99, $\mathrm{GH} \not 500-999.99$, and $\mathrm{GH} \varnothing 1000-1499.99$, respectively. The three loan size sums up to
$76.15 \%$ of the population. The percentage of the people who received an amount equal to $\mathrm{GH} \notin 1500$ or above is only $23.85 \%$. This distribution implies that these institutions' loan amount is low, making it insufficient for customers, thus creating an insignificant impact. 
Table 2. Distribution of loan size.

\section{The range of loan size ( GH Cedi's) Percent}

Freq.

\begin{tabular}{lcc}
\hline $250-499.99$ & 22.42 & 361 \\
$500-999.99$ & 33.04 & 532 \\
$1000-1499.99$ & 20.68 & 333 \\
$1500-2999.99$ & 10.87 & 175 \\
$3000-4999.99$ & 6.96 & 112 \\
$\mathbf{5 0 0 0}$ and more & $\mathbf{6 . 0 2}$ & $\mathbf{9 7}$ \\
Total & $\mathbf{1 0 0}$ & $\mathbf{1 , 6 1 0}$ \\
\hline
\end{tabular}

Source: ICPSR 2020

\subsection{An empirical results analysis}

Table 3 used a logistic model to present the factors that affect farmers' access to microfinance credit from the lenders' perspective.

\subsubsection{Estimating results: Sources of capital}

Sources of microfinance capital play a key role in its operation. The self-sufficiency and sustainability of microfinance depend much on capitalization. Therefore, a weak or overreliance on the third party for capital reinforcement may lead to this institution's failure to perform its core business and not provide credit to the needed clients. The logistic model has shown that microfinance capital sources influence farmers' access to microfinance credit with marginal effects of $0.0693(6.9 \%$ ) (Table 3 ). This correlation is consistent with previous studies that found that microfinance capital structure has a close relationship with its financial performance (Parvin et al. , 2020; Tchuigoua, 2015; Wagner and Winkler, 2013). The study found out microfinance institutions that rely on external debt are likely to fail to perform their core business to help the poor and threatening the ability to give out credit to their clients. This study is also consistent with research conducted in Ghana, which found out that microfinance institutions that use high leverage and finance their operations long-term against short-term debt perform better (Kyereboah - Coleman, 2007). This relationship evidence supports the idea that reliable microfinance capital sources will increase farmer's access to credit. It further substantiates lenders will deny Ghanaian farmers access to credit because of the unreliable and inadequate microfinance institutions' capitalization.

\subsubsection{Estimating results: assets ownership}

Asset ownership was used as a proxy in this study to measure the agricultural credit borrowers' income level. 
Table 3. Results of logistic regression.

\begin{tabular}{|c|c|c|c|}
\hline$Y($ Access to credit) & Coefficients & Std. error & Average Marginal effects (AME) \\
\hline \multicolumn{4}{|l|}{ Explanatory Variables } \\
\hline \multicolumn{4}{|l|}{ Sources of microfinance } \\
\hline capital & 1.9688 & 0.1392 & $0.0693^{* * *}$ \\
\hline \multicolumn{4}{|l|}{ Asset Ownership } \\
\hline Land Ownership & 0.6143 & 0.2332 & $0.0216^{* *}$ \\
\hline House Ownership & 0.1494 & 0.2398 & 0.0053 \\
\hline Car Ownership & -0.4207 & 0.4150 & -0.0148 \\
\hline \multicolumn{4}{|l|}{ Household characteristics } \\
\hline Marital status & 0.2398 & 0.2624 & 0.0084 \\
\hline Gender & -2.1014 & 0.2318 & $-0.0739 * * *$ \\
\hline Family size & 0.0276 & 0.0536 & 0.0010 \\
\hline literacy & 0.1592 & 0.0793 & $0.0056^{* *}$ \\
\hline Age & -0.0073 & 0.0088 & -0.0003 \\
\hline \multicolumn{4}{|l|}{ Institution Affiliations: } \\
\hline Savings account & 0.7717 & 0.1738 & $0.0271 * * *$ \\
\hline Member of MFI & 1.2197 & 0.1177 & $0.0426 * * *$ \\
\hline \multicolumn{4}{|l|}{ Geographical area } \\
\hline Location & 0.3237 & 0.0768 & $0.011 * * *$ \\
\hline Constance & -3.9029 & 0.6822 & \\
\hline \multicolumn{4}{|l|}{ Goodness of fit } \\
\hline Number of Observation & 2734 & & \\
\hline Log of Likelihood & -358.649 & & \\
\hline LR Chi-Square (12) & 2982.09 & & \\
\hline Probability Chi-Square & 0.000 & & \\
\hline Pseudo $\mathrm{R}^{2}$ & 0.806 & & \\
\hline
\end{tabular}


Lenders of agricultural credit measure agricultural credit borrowers' wealth to secure their credit to minimize credit risk associated with agricultural credit. The coefficient estimation of land ownership in the logistic model is statistically significant and positively impacts credit access. The land gives a coefficient of 0.6143 (Table 3) at a $1 \%$ significant level and average marginal effects of $0.0216(2.7 \%)$. The estimated results above show that farmers with ownership of land can have about a $2.7 \%$ chance to get access to microfinance credit than those who do not have land on their own. The variables' significant and positive impacts make theoretical sense, as proven in the previous studies by Ibrahim and Aliero (2012), Kedir (2003). This result can be attributed to the fact that a farmer's technology level can be measured by the availability of a machine used on his farm. A high technological level can increase a farmer's productivity. In this case, a farmer stands to have a higher chance of contracting a microfinance loan.

3.2.3 Estimating of results: Household characteristics

Household social demographics characteristics influence credit rationing by a lender. Certain features of a particular household can determine whether lenders should grant their credit to a household. The estimated results from table 3 show that household characteristics such as literacy and gender are statistically significant. Literacy has a positive impact, while gender has a negative impact. Gender was found to be significant at a $1 \%$ level with a given average marginal effect of $-0.0739(-7.4 \%)$, while literacy was found to be significant at a $5 \%$ level with a given average marginal effect of 0.0056. This study's findings are consistent with similar research conducted by Hemtanon and Gan (2020), which found out that high-educated people are likely to have access to microfinance credit. Farmers who can read and write can use modern agricultural technology; hence, lenders consider it. In his research, Brana (2013) also found that gender influences credit providers' decision to grant credit to their clients. He posited that many microfinance institutions target women primarily because of higher repayment rates, the benefit their family receives from extra income, and a high success rate of group loans among women. Concerning gender issues, women are considered creditworthy with a small amount of credit given to them. Male has a higher capacity to secure a larger amount of loan than their female counterparts do. Men's tendency to secure a larger amount of loans makes them look down on the smaller amount given by microfinance money lenders and diversion of the loan. In this case, females have more advantages than their male counterparts do. Marital status, family size, and age were found not to be statistically significant in this study. The estimated results confirmed the lenders' various accounts, and it has shown that household characteristics influence lenders' decisions.

3.2.4 Estimating results: institution affiliations

Lenders of agricultural credit check the financial background of clients to know their level of creditworthiness. They conduct this research through affiliation members or with their institution records of household members. With the logistic model used, the estimated results show that financial institutions' membership influences farmers' access to microfinance credit. The results show that savings account strongly correlate with farmers' access to microfinance credit with marginal effects of $0.0271(2.7 \%)$. This study's findings 
were consistent with previous studies that found that membership to particular microfinance institutions increases clients' access to microfinance credit (Linh et al., 2019; Hashemi et al., 1996; Hulme and Mosley, 1996). Similar studies conducted by Rogg (2000), Asamoah et al. (2015) also found that microfinance institutions' savings increase clients' access to microfinance credit. These results make sense in reality, as background information is vital in credit assessment. Microfinance institutions sometimes use savings made by household members in the form of security. These measures affect a member who does not have savings with a bank because these institutions' clients mostly find it difficult to provide the lenders' collateral security.

\subsubsection{Estimation results: geographical area}

The microfinance institution highly considers transaction costs before the loan can be granted to household members. Lenders consider this situation because they want to know the processing and monitoring costs after loan disbursement. Microfinance credit providers ensure that borrowers can be easily be located for monitoring and they are available when repayment is due. Ghana is divided into ten administrative regions. The location here refers to where a household is located in each of the administrative regions. This variable was statistically significant and positive, with an average marginal effect of $0.0114(1.1 \%)$. Concerning geographical location and farmers' access to microfinance credit, our results are consistent with other studies analyzing physical distance and access to microfinance credit (Allen et al., 2020; Brown et al., 2013; Alimukhamedova et al., 2017). They revealed that microfinance's physical distance significantly affects the business operations and clients' credit accessibility. This study's findings make sense in reality as people in the deprived community find it difficult to access financial services because of the proximity. Credit suppliers usually consider the development and climatic conditions within regions before loan disbursement. The microfinance institution in Ghana takes into consideration the geographical location of the clients to make monitoring easy.

\section{Conclusion and Recommendations}

Farmers' access to microfinance credit in Ghana is low. This study's objective was to empirically assess the effects of microfinance capital sources on farmers' access to credit. It was based on a large sample $(N=2734)$ drawn from the Inter-University Consortium for Political and Social Research (ICPSR) project. A logistic regression model was used, and marginal effects were computed after estimation. We hypothesized that sources of microfinance capital have effects on the farmers' access to microfinance credit. The study has shown that microfinance capital influences farmers' access to microfinance credit in Ghana. The study also revealed that land ownership, gender, literacy, marital status, savings, membership of MFI, and geographical location significantly influence farmers' access to Microfinance credit in Ghana. Therefore, we accept our hypothesis. Given the findings, it can confirm that farmers face challenges in accessing microfinance credit. There is a need to employ comprehensive strategies that can increase farmers' access to credit. These strategies will help farmers improve their farm produce to mitigate food shortages, considering the crucial role of microfinance institutions. Some of the necessary comprehensive strategies that can be adopted to increase 
farmers' access to credit facilities based on these studies are given below:

The research has revealed that agricultural farmers' primary problem with accessing credit from microfinance institutions is the source of microfinance capital. Microfinance needs innovative ways of financing to improve capitalization. Microfinance models' finance sources, such as self-help groups (SHG), financial intermediation, and partnership, will help accumulate enough business operation capital. This study has shown that the major agricultural credit comes from a rural bank, credit unions, non-governmental organizations, and cooperatives. The government needs to collaborate with many development agencies to establish specialized credit institutions that cater to these farmers' credit needs to improve their credit access. Also, the proximity of microfinance institutions to the people was another significant factor affecting credit access. Government or development agencies need to develop some strategy to establish broader network branches to serve communities that lack access to credit due to proximity. Therefore, there is a need to form cooperative groups, farmers associations, or any other type of group responsible for administration and supervision of the credit facilities at the local community level, which can improve repayment and increase their chance of credit. Furthermore, gender imbalances about access to credit where women have more chances to get a microfinance credit loan in rural communities need to avoid gender bias. Gender balances need to be established where males and females would be given equal opportunity to institutional credit to improve the household's general accessibility of loan facilities. In this way, there is a need to strengthen the capacity and effective utilization of credit to enhance credit access to both genders and avoid biases in credit allocation. Credit facilities should be based on a reasonably competitive system through the applicant's investment creditworthiness.

Finally, land ownership, which facilitates access to credit, is a little complex to deal with by nature, but proper documentation through registration to ensure land ownership security can help these farmers secure loans for their agricultural production.

\section{References}

Agier I. and Szafarz A. (2013) 'Subjectivity in credit allocation to micro-entrepreneurs: Evidence from Brazil' Small Business Economics, 41(1), pp. 263-275.

Allen F., Carletti E., Cull R., Qian J., Senbet L. W., and Valenzuela P. (2020) 'Improving access to banking: Evidence from Kenya' The World Bank Development Research Group.

Alimukhamedova N., Filer R., and Hanousek J. (2017) 'The importance of geographic access for the impact of microfinance' Development Policy

Review, 35(5), pp. 645-657.Al-Mamun A., Mohiuddin M., and Mariapun S. (2014) 'Investigating the effects of Amanah Ikhtiar Malaysia's microcredit programmes on employment in rural Malaysia' Journal of Southeast Asian Economies 31(3), pp. 471-483.

Anang B.T., Sipiläinen T., Bäckman S., and Kola J. (2015) 'Factors influencing smallholder farmers' access to agricultural microcredit in Northern Ghana' African Journal of Agricultural Research, 10(24), pp.2460-2469. 
Anderson C.L., Locker L., and Nugent R. (2002) ' Microcredit, social capital, and common pool resources 'World development, 30(1), pp.95-105.

Annim, Samuel, Awusabo-Asare, Kofi, Abane, Albert, Amonoo, Edwin, and Acheampong, Isaac (2014) 'Poverty Assessment and a Comparative Study of Rural Microfinance Institutions and Government Programmes in Ghana' Inter-university Consortium for Political and Social Research (ICPSR) Ann Arbor, Michigan, USA.

Asamoah M., Darkwah A., and Amoah F. M. (2015) 'Microcredit Schemes: A Tool for Promoting Rural Savings Capacity among Poor Farm Families: A Case Study in the Eastern Region of Ghana' Open Journal of Social Sciences, 3(01), p.24.

Bali S. R. (2001). 'Demand, Segmentation, and Rationing in the Rural Credit Markets of Puri ' Doctoral Thesis, Uppsala University, Sweden.

Berhane G. and Gardebroek C. (2011) 'Does microfinance reduce rural poverty? Evidence based on household panel data from northern Ethiopia' American Journal of Agricultural Economics, 93(1), pp.43-55.

Berry L. (1995) 'Area Handbook Series: Ghana: A Country Study' Library of Congress Washington Dc Federal Research Div.

Bhanot D., and Bapat V. (2015) 'Sustainability index of microfinance institutions (MFIs) and contributory factors' International Journal of Social Economics, 42(4), pp. 387-403

Boateng G.O., Boateng A.A. and Bampoe H.S. (2015) 'Microfinance and Poverty Reduction in Ghana: Evidence from
Policy Beneficiaries' Review of Business \& Finance Studies, 6 (1), pp. 99-108.

Bogan V.L.( 2012) 'Capital structure and sustainability: An empirical study of microfinance institutions 'Review of Economics and Statistics, 94(4), pp.1045-1058.

Boucher S. and Guirkinger C. (2007) 'Credit constraints and productivity in Peruvian agriculture ' Working Paper No. 07005, Department of Agriculture and Resource Economics, University of California, Davis, CA.

Brana S. (2013) 'Microcredit: an answer to the gender problem in funding? 'Small Business Economics, 40(1), pp. 87-100.

Brown M., Guinn B., and Kirshenmann K. (2013) 'Microfinance Banks and Household Access to Finance' Working paper. Retrieved from http://uxtauri.unisg.ch/RePEc/usg/sfwpfi/WPF1302.pdf.

Cameron A. C., and Trivedi P. K. (2010) 'Microeconometrics using Stata (Vol. 2) ' Stata Press College Station, Texas, USA. Diaz-Serrano L. and Sackey F. G. (2018) 'Microfinance and credit rationing: does the microfinance type matter? ' Journal of Sustainable Finance \& Investment, 8(2), pp. 114-131.

Food and Agriculture Policy Decision Analysis (FAPDA)(2015) 'Country Fact sheet on food and agriculture policy trends, ' Food and Agricultural Organisation of the United Nations. FAO. (Retrieved 10 May 2020.) 
Fehr D. and Hishigsuren G. (2006) 'Raising capital for microfinance: Sources of funding and equity for equity financing' Journal of Developmental Entrepreneurship, 11(02), pp.133143.

Ferede K.H. ( 2012) 'Determinants of Rural Households Demand for and Access to Credit in Microfinance Institutions: The Case of Atamata Woreda-Ethiopia' MA. Wageningen University Research Centre Wageningen, the Netherlands.

Greene W.H. (2003) 'Econometric Analysis' Fifth Edition, Pearson Education, Inc. Institutional and Financial Perspective, The World Bank, Washington, DC.

Hashemi S. M., Schuler S. R. and Riley A. P. (1996) 'Rural credit programs and women's empowerment in Bangladesh' World development, 24(4), pp. 635-653.

Hemtanon W. and Gan C. (2020) 'Microfinance Participation in Thailand ' Journal of Risk and Financial Management, 13(6), p.122.

Henning J. I., Bougard D. A., Jordaan H., and Matthews N. (2019) 'Factors Affecting Successful Agricultural Loan Applications: The Case of a South African Credit Provider' Agriculture, 9(11), p. 243.

Hulme D. and Mosely P. (1996) 'Finance Against Povert ' Volume 1, pp. 105-137. Routledge, New York.

Ibrahim S.S. and Aliero H. M. (2012) 'An Analysis of Farmers' Access to Formal Credit in the Rural Areas of Nigeria' African Journal of Agricultural Research, 7(47), pp. 6249-6253.

Kar A.K. ( 2012) 'Does capital and financing structure have any relevance to the performance of microfinance institutions? ' International Review of Applied Economics, 26(3), pp.329-348.

Kedir A. (2003) 'Determinants of Access to Credit and Loan Amount: HouseholdLevel Evidence from Urban Ethiopia' International Conference on Development Studies July 11-12, 2003, Addis Ababa, Ethiopia Paper 64

Khalid M. (2003) 'Access to Formal and QuasiFormal Credit by Smallholder Farmers and Artisanal Fishermen: A Case of Zanzibar' Ministry of Agriculture. Natural Resources, Environment and Cooperation, Zanzibar, Tanzania Research on Poverty Alleviation. Research Report (03.6), p.35.

Khavul S. (2010) 'Microfinance: creating opportunities for the poor?' The Academy of Management Perspectives, 24(3), pp.58-72.

Kiplimo J.C. (2015) 'Determinants of access to credit by smallholder farmers in Eastern and Western Kenya' (Doctoral dissertation). Strathmore University.

Kyereboah-Coleman A. (2007) 'The impact of capital structure on the performance of microfinance institutions ' The Journal of Risk Finance. 8(1), pp.56-71

Langat R.C. (2013) 'Determinants of lending to farmers by commercial banks in Kenya' (Doctoral dissertation). University of Nairobi

Leeper T.J. (2017) 'Interpreting regression results using average marginal effects with R's margins' Available at the comprehensive $\mathrm{R}$ Archive Network (CRAN), pp.1-32. 
Li X., Gan C., and Hu B. (2011) 'Accessibility to microcredit by Chinese rural households' Journal of Asian Economics, 22(3), pp.235-246.

Linh T.N., Long H.T., Chi L.V., Tam L.T. and Lebailly P. (2019) 'Access to rural credit markets in developing countries, the case of Vietnam: A literature review' Sustainability, 11(5), p.1468.

Ngo T.V., (2013) 'Capital structure and microfinance performance: a crosscountry analysis and case study of Vietnam' (Doctoral dissertation, University of Birmingham).

Nouman M., Siddiqi M.F., Asim S.M, and Hussain Z. (2013) 'Impact of SocioEconomic Characteristics of Farmers on Access to Agricultural Credit' Sarhad Journal of Agriculture, 29(3), pp.469-476.

Parvin S. S., Hossain B., Mohiuddin M., and Cao Q. (2020) 'Capital Structure, Financial Performance, and Sustainability of Micro-Finance Institutions (MFIs) in Bangladesh' Sustainability, 12(15), p.6222.

Rogg C. S. (2000) 'The impact of access to credit on the saving behavior of microentrepreneurs: Evidence from 3 latin American countries' Inter-American Development Bank Publications, University of Oxford, London.

Rooyen V. C., Stewart R. and De Wet T. (2012) 'the impact of microfinance in subSaharan Africa: a systematic review of the evidence' World Development, 40(11), pp.2249-2262.

Santandreu E. M., López Pascual J., and Cruz Rambaud S. (2020) 'Determinants of Repayment among Male and Female
Microcredit Clients in the USA. An Approach Based on Managers' Perceptions' Sustainability, 12(5), p.1701.

Sekabira H. (2013) 'Capital structure and its role on performance of microfinance institutions: The

Ugandan case' Sustainable Agriculture Research, 2(5262016-37778).

Sekyi S. (2017) 'Rural households' credit access and loan amount in $\mathrm{Wa}$ Municipality, Ghana. International Journal of Economics and Financial Issues, 7(1), pp.506-514.

Stiglitz J. E., and WeissA. (1981) 'Credit rationing in markets with imperfect information' The American economic review, 71(3), pp.393-410.

Swain R.B. and Wallentin F.Y. (2009) 'Does microfinance empower women? Evidence from self help groups in India' International review of applied economics, 23(5), pp.541-556.

Tchuigoua H. T. (2015) 'Capital structure of microfinance institutions' Journal of Financial Services Research, 47(3), pp.313-340.

Umanath M., Paramasivam R., Kavitha V. and Thangadurai T. (2018) 'Determinants of demand for formal agricultural credit in rural India' Asian Journal of Agricultural Extension, Economics \& Sociology, 28(1), pp.1-7.

Wagner C. and Winkler A. (2013) 'The vulnerability of microfinance to financial turmoil-evidence from the global financial crisis' World Development, 51(11), pp.71-90. 
Wooldridge J.M. (2009) 'Introductory econometrics a modern approach' USA: South-Western Cengage Learning

Zeller M. (1994) 'Determinants of credit rationing: A study of informal lenders and formal credit groups in Madagascar' World development, 22(12), pp.18951907.

Zumel N. (2014) 'The simpler derivation of logistic regression' URL http://www. win-vector. com/blog/2011/09/thesimpler-derivation-of-logisticregression/. (Accessed On, February 2020) 